\title{
Comparison of Outcome of Early versus Delayed Hemisoleus Flap coverage of Open Wound over the Middle one Third of Leg after Fracture of Tibia \\ Muhammad Usman, ${ }^{1}$ Muhammad Saad Faisal, ${ }^{1}$ Muhammad Aslam Channa, ${ }^{1}$ Barira Bashir ${ }^{1}$
}

\begin{abstract}
Background: Fracture of tibia are quite common and wound coverage is usually needed in its management.

Objective: To compare the outcome of early versus delayed hemisoleus flap coverage, of open wound over the middle one third of leg after fracture of tibia.

Methodology: This randomized controlled trial, was conducted over a year, in the Department of Plastic Surgery, Nishtar Hospital, Multan, including 240 patients, with open tibial shaft fractures, who had early (Group A) or delayed coverage (Group B). Both the groups were compared for outcome parameters (excellent, good, fair and poor) used by Haq et al, at six weeks after the procedure. Chi-square test was applied for test of significance. P-value $<0.05$ was considered significant. Data was analyzed with the help of SPSS version 20.

Results: In group A, excellent, good, fair and poor outcome, were seen in 48 (40\%), 45 (37.5\%), 25 (20.8\%) and 2 $(1.7 \%)$ patients, respectively. In group B, excellent, good, fair and poor outcome, were seen in $0(0 \%), 60(50 \%)$ patients, $18(15 \%)$ and $42(35 \%)$ patients, respectively. The results were statistically significant on comparison of the two groups $(\mathrm{p}<0.05)$.

Conclusion: Early coverage of open tibial shaft fracture results in higher frequency of excellent and good outcome as compared to delayed coverage.
\end{abstract}

Key words: Hemisoleus flap, Early reconstruction, Delayed reconstruction, Tibia, Fracture

\section{Introduction}

As frequency of motor bike accidents in developing countries is rising day by day so, there is an increase in open fractures of tibia. ${ }^{1,2}$ Fractures of tibia are presented as isolated injury as well as part of polytrauma. ${ }^{3,4}$ Management of open fractures of tibia is a challenge for the surgeons because of dirty wound that demands serial debridement, external and later internal fixation of fracture and coverage of wound defect. ${ }^{5,6}$ Open fracture of tibia requests for skills of both orthopedic and plastic surgeon. ${ }^{7,8}$ Soft tissue defects can be covered by flaps of microvascular and non-microvascular types. ${ }^{9,10}$

Non-microvascular flaps are technically easy to develop as compared to microvascular flap that require skillful learning and experience. ${ }^{11,12}$ Failure rate of microvascular flaps is higher so, to decrease burden of morbidity, non-microvascular flaps are encouraged these days to lessen the misery of fractured limb. ${ }^{13,14}$ Open fractures of shaft of tibia are always posing serious, challenge to orthopedic surgeon. ${ }^{15,16}$

Coverage with hemisoleus flap is in practice, now a days. However, there is no consensus on the time of coverage. Some surgeons favor early closure (0-7 days) while others prefer delay closure (8-40 days) of trauma. We conducted this study to assess and compare the outcome of early versus delayed hemisoleus flap coverage, of the open wound, over the middle one third of leg, after fracture of tibia.

\section{Methodology}

This randomized controlled trial, was conducted in the Department of Plastic Surgery, Nishtar Hospital, Multan, from January to December 2014. This study included 240 patients, with distal fracture of tibia and having open wound with loss of skin in at least $5 \mathrm{~cm}$ area over the tibia of either gender and between 20 to 45 years of age. Only the patients with Gustilo Anderson classification type IIIb, were included in this study. Patients with pathological fractures of tibia (X-rays showing osteolytic lesions), sepsis (patients having fever $(>102 \mathrm{oF})$ and blood cultures positive for bacteria and patients presenting after 24 hours after injury, were excluded from the study. Patients were divided into two groups; Group A, 120 patients in this group, received early coverage (within 7 days of surgery) and Group B, 120 patients

1. Sharif Medical and Dental College, Lahore, Pakistan.

Correspondence: Dr. Muhammad Saad Faisal, Associate Professor, Department of Surgery, Sharif Medical City Hospital, Lahore, Pakistan.

Email:saadi206@yahoo.com

Received: 16-08-2019

Accepted: 14-11-2019 Published: 25-12-2019 
in this group received delayed coverage (within 8 -30 days of trauma).

Surgical technique: All patients were operated under general anesthesia in supine position after tourniquet application. A skin incision $2 \mathrm{~cm}$ away and parallel to medial edge of tibia was made posteriorly. Proximal and distal end of defect was extended into this incision. Soleus muscle was recognized. Medial half of muscle was raised, divided distally and splitted longitudinally. Flap was moved to cover defect. Donor area was approximated over a suction drain. An above knee POP slab and limb elevation for 1 week were advised postoperatively.

All the patients were observed for the outcome parameters (excellent, good, fair or poor), used by Haq et al, ${ }^{17}$ at six weeks after the procedure, as shown in table I. Demographic features, history and physical examination were noted. The data was entered into SPSS version 20, computer program and analyzed accordingly. The qualitative data like demographics (sex; male or female), the outcome parameters (excellent, good, fair or poor) were presented as frequency and percentage. The two groups were compared for any statistical significance. Chi-square test was applied for the outcome parameters. P-value < 0.05 was significant. Informed consent was taken from each patient for inclusion in study groups. Ethical approval was sought from ethical committee of hospital.

Table I: Criteria as described by Haq et al. ${ }^{17}$

\begin{tabular}{|l|l|l|l|}
\hline Criteria & A & B & C \\
\hline Skin condition & Normal & $\begin{array}{l}\text { Slightly } \\
\text { discolored }\end{array}$ & $\begin{array}{l}\text { Ulcer or fistula, } \\
\text { persistent } \\
\text { infection }\end{array}$ \\
\hline $\begin{array}{l}\text { Muscle } \\
\text { atrophy }\end{array}$ & $0-1 \mathrm{~cm}$ & $1-2 \mathrm{~cm}$ & $>2 \mathrm{~cm}$ \\
\hline Deformity & None & $\begin{array}{l}\text { Slight, not } \\
\text { noticeable }\end{array}$ & $\begin{array}{l}\text { Considerable, } \\
\text { noticeable, } \\
\text { shortening }>2 \mathrm{~cm}\end{array}$ \\
\hline $\begin{array}{l}\text { Loss of knee } \\
\text { movement }\end{array}$ & $<10$ degree & $10-20$ & $>20$ \\
\hline $\begin{array}{l}\text { Loss of ankle } \\
\text { movement }\end{array}$ & $<5$ & $5-10$ & $>10$ \\
\hline Deep infection & $\begin{array}{l}\text { Mild } \\
\text { asymptomatic }\end{array}$ & Moderate & $\begin{array}{l}\text { sever } \\
\text { symptomatic }\end{array}$ \\
\hline $\begin{array}{l}\text { Radiological } \\
\text { evidence of } \\
\text { healing }\end{array}$ & $\begin{array}{l}\text { Complete } \\
\text { healing }\end{array}$ & Delayed union & $\begin{array}{l}\text { Established non } \\
\text { union }\end{array}$ \\
\hline $\begin{array}{l}\text { Return to } \\
\text { employment }\end{array}$ & $\begin{array}{l}\text { Activities } \\
\text { unchanged }\end{array}$ & $\begin{array}{l}\text { Incapacitated } \\
\text { for some work }\end{array}$ & Stops work \\
\hline
\end{tabular}

Results were classified into excellent, good, fair and poor groups. Excellent; All of the criteria of grade A, Good ; All of the criteria of grade B, Fair; One criterion of grade $\mathrm{C}$ and others of grade $\mathrm{A}$ or $\mathrm{B}$ and Poor; More than one criteria of grade $\mathrm{C}$.

\section{Results}

Two hundred and forty patients were included in the study. Overall characteristics of patients of tibial fractures in both groups are shown in Table II. The mean age of the patients in group A and B, were $34.75 \pm 5.08$ and $32.03 \pm 7.13$ years, respectively. In group A, there were $83(69.2 \%)$ male patients and 37 $(30.8 \%)$ female patients. In group B, there were 91 $(75.8 \%)$ male patients and $29(24.2 \%)$ female patients. The male to female ratio was 2.6:1. Outcome and postoperative complications of early versus delayed hemisoleus flap coverage of open wound over the middle one third of leg after fracture of tibia are shown in table III and IV, respectively.

Table II: Characteristics of patients and tibial fractures $(n=240)$

\begin{tabular}{|c|c|c|}
\hline \multicolumn{2}{|r|}{ Variables } & $\begin{array}{c}\text { No. of } \\
\text { patients }(\%)\end{array}$ \\
\hline \multirow[t]{2}{*}{ Age (years) } & Mean \pm SD & $33.41 \pm 6.73$ \\
\hline & Range & $22-41$ \\
\hline \multirow[t]{2}{*}{ Gender } & Male & $174(73.0 \%)$ \\
\hline & Female & $66(27.5 \%)$ \\
\hline \multirow{4}{*}{$\begin{array}{l}\text { Co- } \\
\text { morbidities }\end{array}$} & Diabetes mellitus & $8(3.0 \%)$ \\
\hline & Hypertension & $24(10.0 \%)$ \\
\hline & Ischemic heart disease & $1(0.4 \%)$ \\
\hline & Others & $0(0.0 \%)$ \\
\hline \multirow{4}{*}{$\begin{array}{l}\text { Types of } \\
\text { tibial shaft } \\
\text { fractures }\end{array}$} & Transverse & $164(68.0 \%)$ \\
\hline & Oblique & $41(17.0 \%)$ \\
\hline & Spiral & $14(6.0 \%)$ \\
\hline & Comminuted fracture & $21(8.8 \%)$ \\
\hline
\end{tabular}

Table III: Outcome of Early versus Delayed Hemisoleus Flap coverage of Open Wound over the middle one third of leg after Fracture of Tibia $(n=240)$

\begin{tabular}{|l|l|l|l|l|}
\hline \multirow{2}{*}{$\begin{array}{l}\text { Outcome } \\
\text { parameters }\end{array}$} & \multicolumn{3}{|l|}{ Group A } & Group B \\
\cline { 2 - 5 } & $\begin{array}{l}\text { No. of } \\
\text { patients }\end{array}$ & Percentage & $\begin{array}{l}\text { No. of } \\
\text { patients }\end{array}$ & Percentage \\
\hline Excellent & 48 & 40.0 & 0 & 0.0 \\
\hline Good & 45 & 37.5 & 60 & 50.0 \\
\hline Fair & 25 & 20.8 & 18 & 15.0 \\
\hline Poor & 2 & 1.7 & 42 & 35.0 \\
\hline p-value & 0.001 & \multicolumn{2}{|l}{} \\
\hline
\end{tabular}




\section{Discussion}

Open fractures of the tibia are a difficult problem to treat. Deep infection, malunion, delayed union, and nonunion have all been reported after these fractures. Treatment options may be limited. Proximally based muscle flaps have been used with varying amounts of success. In this study, outcome of early versus delayed hemisoleus flap covering was compared among 240 patients. This is one of the largest study nationwide to include this much large sample size. The results of the study favored the early flap coverage as compared to delayed coverage with $77.5 \%$ frequency of excellent and good outcome with early coverage as compared to $50 \%$ frequency of excellent and good outcome with delayed coverage.

The mean age of the patients in our study was $34.75 \pm 5.08$ years in one group and $32.03 \pm 7.13$ years in other group. In study by Syed AT et al, ${ }^{15}$ the mean age of the patients was 46.5 years. In study by Debbarma $\mathrm{S}$ et al, ${ }^{16}$ the average age of patients in one group was 23 years while that of patients in second group was 28.4 years. Majority of the patients were in younger age group i.e. $33.3 \%$ patients were in age group of $31-35$ years in group A, and $35 \%$ patients were in age group 20 - 25 years. In our study, the majority of the patients were male i.e. $69.2 \%$ in group $\mathrm{A}$ and $75.8 \%$ in group B. This had also been verified by Syed AT, et al ${ }^{15}$ who showed that $77.8 \%$ patients were male. Similarly, Ul-Haq A, et al, ${ }^{17}$ showed that $80 \%$ population of their study was male. This can also be due to the fact that male gender is more prone to the accidents or trauma.

In our study, excellent results were achieved with early closure (i.e. $40 \%$ ) and good results in $37.5 \%$ patients while with delayed closure, none of the patients had excellent outcome, while 50\% patients showed good outcome. Previously, U1Haq A et al $^{17}$ also conducted a study to compare the outcome of early versus delayed closure. They found that with early wound coverage, the result was excellent in $37.5 \%$ cases, good in $37.5 \%$ cases and fair in $25 \%$ cases. With delayed wound coverage, the outcome was good in $37.5 \%$ case; fair in $12.5 \%$ case and poor in $50 \%$ cases. The results of this study concluded that early coverage of the exposed bone in open tibial shaft fracture hold better outcomes.

One of the characteristics of our study was that we used the scoring system, that was used by U1-Haq
A et al. ${ }^{17}$ This scoring system was based in skin changes, muscle activity, joint movements, non union and return to the employment. So, this study had the advantage of using the more physiological and functional parameters rather than subjective parameters like pain, or objection parameters like infection and non union. ${ }^{17}$

In our study, we preferred medial hemisoleus muscle flap over the whole Soleus muscle because of its longer arc of rotation and minimal functional loss of foot plantar flexion. When whole Soleus muscle flap is used, its lateral half is usually wasted to traverse the deep flexors where it is not needed. The lateral half also limits the arc of rotation thus hindering the reach of flap. ${ }^{17}$ Whole Soleus muscle flap has to be orientated transversely/obliquely whereas hemisoleus muscle flap can be orientated more obliquely/longitudinally because its pivot point lies nearer to the tibia. Due to this geometrical advantage medial hemisoleus muscle flap can cover equally long or sometimes even longer defects than complete Soleus muscle flap. As medial hemisoleus muscle flap is less bulky than the whole Soleus muscle flap, the reconstructive outcome is usually cosmetically better than the whole muscle. Anatomy of the Soleus muscle has been explored thoroughly, providing the basis for the technically more comfortable and safe dissection of this flap. The bipennate nature of the Soleus and the independent neurovascular supply to both medial and lateral halves of the muscle are the key anatomical features that allow splitting the muscle longitudinally along the raphe. The most significant advantage of hemisoleus muscle flap is preservation of foot plantar flexion power by the hemisoleus muscle belly left in situ. The medial half of the muscle is supplied constantly throughout its length by the perforators from the posterior tibial artery. This feature makes medial hemisoleus muscle flap more reliable than the lateral half. ${ }^{17}$

This study has certain limitations. This was not a double blind study, as it was not possible because both the procedures were done at different timings. Moreover, this was carried out in a single setup with a limited population size.

\section{Conclusion}

This study concludes that early coverage of open tibial shaft fracture results in higher frequency of excellent and good outcome as compared to delayed coverage and the results were statistically 
significant. So, early coverage of open tibial shaft fracture should be preferred in routine practice.

Authors Contribution: MU: Conception and revising. MSF: Design of work and drafting. MAC: Acquisition and analysis and revising. BB: Interpretation and drafting. All the authors gave the final approval for publishing and agreed to be accountable for all aspect of work.

\section{Conflict of Interest: None Sources of Funding: Self}

\section{References}

1. Fernandez MA, Nanchahal J, Costa ML. Open tibial fractures. Orthop Trauma 2017;31(2): 125-32.

2. Diwan A, Eberlin KR, Smith RM. The principles and practice of open fracture care. Chin J Traumatol 2018; 21(4): 187-92.

3. Kamath JB, Shetty MS, Joshua TV, Kumar A. Soft tissue coverage in open fractures of tibia. Indian $\mathrm{J}$ Orthop 2012; 46(4): 462-69

4. Hafeez K, Abbas K. Use of distally based random flap in the management of soft tissue defects in upper two thirds of leg. JPMA 2014; 64(12): 15-8.

5. Cherubino M, Corno M, D'Arpa S, Di Summa P, Pellegatta I, Valdatta L, Ronga M. Muscle versus fasciocutaneous flap in lower limb reconstruction: is there a best option?. J Reconstr Microsurg 2017; 33(1): 27-33.

6. Steiert AE, Gohritz A, Schreiber TC, Krettek C, Vogt PM. Delayed flap coverage of open extremity fractures after previous vacuum-assisted closure (VAC®) therapy-worse or worth?. J Plast Reconstr Aesthet Surg 2009; 62(5): 675-83.

7. Mahajan RK, Srinivasan K, Singh M, Jain A, Kapadia T, Tambotra A. Management of Post-Traumatic Composite Bone and Soft Tissue Defect of Leg. Indian J Plast Surg 2019; 52(1): 45-54.
8. Mathieu L, Potier L, Ndiaye R, Mbaye E, Sene M, Faye M, Niang CD. Management of Gustilo type IIIB open tibial shaft fractures with limited resources: experience from an African trauma center. ESTES 2019; 3: 1-7.

9. Ramasamy PR. Management of Gustilo Anderson III B open tibial fractures by primary fascio-septo-cutaneous local flap and primary fixation: The 'fix and shift'technique. Indian J Orthop 2017; 51(1): 55-68

10. Gautam AN, Bhatia VY. Coverage of the lower $1 / 3$ of exposed tibial defect: a prospective study. J Evolution Med Dental Sci 2015; 4(7): 1173-84.

11. Mina DK, Gupta S, Tiwari AK, Meena R, Nama KG. Management of Soft Tissue Complications Associated with Leg Bone Injuries by Local Muscle Pedicle Flap. J Orthop 2017; 22(2); 31-6

12. Yazar S, Lin CH, Lin YT, Ulusal AE, Wei FC. Outcome comparison between free muscle and free fasciocutaneous flaps for reconstruction of distal third and ankle traumatic open tibial fractures. Plast Reconstr Surg 2006; 117(7): 2468-75.

13. Nambi GI, Salunke AA, Thirumalaisamy SG, Babu VL, Baskaran K, Janarthanan T, Boopathi K, Chen YS. Single stage management of Gustilo type III A/B tibia fractures: Fixed with nail \& covered with fasciocutaneous flap. Chin J Traumatol 2017;20(2): 99-102.

14. Gad SS, Kishk TF, Elkashty SM, Bassam MK. Reconstruction of the middle third of the leg by distally based hemigastrocnemius muscle flap. Menoufia Med J 2018; 31(4): 1369-74

15. Sayed AT. Diastally based medial hemi-soleus muscle flap based on the posterior tibial vessels. AAMJ 2009; 7: 337 53.

16. Debbarma S, Singh NS, Singh PI, Singh S N, Singh A M, Meena RK. Fasciocutaneous flap as a method of soft tissue reconstruction in open tibial fractures. J Med Soc 2013; 27 : 100-5.

17. Ata-ul-Haq, Moazzam Nazeer Tarar, Falak Sher Malik, Kamran Khalid, Ahsan Riaz, Mohammad Younas Mehrose, Husnain Khan. Hemisoleus muscle flap, a better option for coverage of open fractures involving middle third of tibia. J Ayub Med Coll Abbottabad 2009; 21: $154-$ 8 .

Article Citation: Usman M, Faisal MS, Channa MS, Bashir B. Comparison of Outcome of Early Versus Delayed Hemisoleus Flap Coverage of Open Wound Over the Middle One Third of Leg after Fracture of Tibia. JSZMC 2019;10(4): 23-26 